\title{
Sub-chronic lung inflammation after airway exposures to Bacillus thuringiensis biopesticides in mice
}

Kenneth K Barfod ${ }^{1,2}$, Steen S Poulsen ${ }^{3}$, Maria Hammer ${ }^{1}$, Søren T Larsen ${ }^{1 *}$

\begin{abstract}
Background: The aim of the present study was to assess possible health effects of airway exposures to Bacillus thuringiensis (Bt) based biopesticides in mice. Endpoints were lung inflammation evaluated by presence of inflammatory cells in bronchoalveolar lavage fluid (BALF), clearance of bacteria from the lung lumen and histological alterations of the lungs. Hazard identifications of the biopesticides were carried out using intratracheal (i.t.) instillation, followed by an inhalation study. The two commercial biopesticides used were based on the Bt. subspecies kurstaki and israelensis, respectively. Groups of BALB/c mice were i.t instilled with one bolus $\left(3.5 \times 10^{5}\right.$ or $3.4 \times 10^{6}$ colony forming units (CFU) per mouse) of either biopesticide. Control mice were instilled with sterile water. BALFs were collected and the inflammatory cells were counted and differentiated. The BALFs were also subjected to CFU counts.

Results: BALF cytology showed an acute inflammatory response dominated by neutrophils 24 hours after instillation of biopesticide. Four days after instillation, the neutrophil number was normalised and inflammation was dominated by lymphocytes and eosinophils, whereas 70 days after instillation, the inflammation was interstitially located with few inflammatory cells present in the lung lumen.

Half of the instilled mice had remaining CFU recovered from BALF 70 days after exposure. To gain further knowledge with relevance for risk assessment, mice were exposed to aerosols of biopesticide one hour per day for $2 \times 5$ days. Each mouse received $1.9 \times 10^{4}$ CFU Bt israelensis or $2.3 \times 10^{3}$ CFU Bt kurstaki per exposure. Seventy days after end of the aerosol exposures, 3 out of 17 mice had interstitial lung inflammation. CFU could be recovered from 1 out of 10 mice 70 days after exposure to aerosolised Bt kurstaki. Plethysmography showed that inhalation of Bt aerosol did not induce airway irritation.

Conclusions: Repeated low dose aerosol exposures to commercial Bt based biopesticides can induce sub-chronic lung inflammation in mice, which may be the first step in the development of chronic lung diseases. Inhalation of Bt aerosols does not induce airway irritation, which could explain why workers may be less inclined to use a filter mask during the application process, and are thereby less protected from exposure to Bt spores.
\end{abstract}

\section{Background}

Regarded as harmless to humans, Bacillus thuringiensis (Bt) is used worldwide as a commercial biopesticide for the pest control of insects. It is typically used in large spray campaigns on open fields or indoor in green houses [1]. The insecticidal effect is largely due to the characteristic ability to produce specific insect toxins

\footnotetext{
* Correspondence: stl@nrcwe.dk

${ }^{1}$ National Research Centre for the Working Environment, Copenhagen, Denmark

Full list of author information is available at the end of the article
}

from crystal toxin genes mostly harboured on large plasmids [2]. Bt is a Gram positive, endospore-forming bacterium closely related to the opportunistic human pathogen Bacillus cereus [3].

Commercial Bt strains have been isolated from human faecal samples and nasal lavage cultures and elevated human IgE antibody levels have been reported after occupational exposure [4-6]. Most epidemiological and occupational studies on biopesticides have focused on immune responses, infection, food poisoning or other gastro-intestinal symptoms [4,7-9]. The possible long-
C Biomed Central

() 2010 Barfod et al; licensee BioMed Central Ltd. This is an Open Access article distributed under the terms of the Creative Commons Attribution License (http://creativecommons.org/licenses/by/2.0), which permits unrestricted use, distribution, and reproduction in any medium, provided the original work is properly cited. 
term effects after repeated pulmonary exposure in humans working with Bt biopesticides have not yet been investigated, although the endospore sizes $(1-2 \mu \mathrm{m}$ in diameter) are within inhalable sizes for humans and mice $[10,11]$. Long-term effect of biopesticide exposure are not likely to be revealed in longitudinal epidemiological studies, since many green house workers are only temporary employed and therefore may have changed occupation at the time of follow-up.

The purpose of the present study was to explore acute and sub-chronic effects of airway exposure to biopesticides, with focus on airway irritation, lung inflammation and clearance of Bt from the lungs. Initially, doseresponse and time-response studies were conducted using i.t. instillations. To simulate occupational exposures, mice were in a subsequent experiment exposed repeatedly by inhalation to aerosolised commercially formulated biopesticides based on $\mathrm{Bt}$ israelensis or $\mathrm{Bt}$ kurstaki.

\section{Methods}

\section{Animals}

The exposures were performed on BALB/cJ female mice (Taconic M\&B, Ry, Denmark), 6-8 weeks old, body weight $18-22 \mathrm{~g}$. Animals were housed up to 10 animals per cage $(425 \times 266 \times 150 \mathrm{~mm})$ and drinking water and food (Altromin no 1324 Brogaard Denmark) was provided ad libitum. Light/dark cycles were at 12 hours and room temperature and relative humidity was kept at $19-22^{\circ} \mathrm{C}$ and $40-60 \%$, respectively. All protocols were approved by the Danish Animal Experiments Inspectorate.

\section{Bacterial suspensions and CFU determinations}

The bacterial suspensions were prepared from commercially available insecticides Vectobac ${ }^{\circledR}$ (Bt israelensis) and Dipel $^{\circledR}$ (Bt kurstaki) from Valent Biosciences (Sumitomo Chemical Agro Europe, Lyon, France). The suspensions for aerosol generation and intratracheal instillation were prepared from the formulated products by suspending them in sterile, endotoxin-free water. To reduce viscosity (caused by additives) during the high dose instillations of Dipel ${ }^{\circledR}$, mice in one group (experiment 4, cf. Table 1) received product that was subjected to a washing procedure: the Dipel $^{\oplus}$ was suspended and centrifuged and supernatant discharged. This procedure was repeated twice. The final precipitate was re-suspended in sterile water and adjusted for CFU counts.

All bacterial morphology and CFU determinations were performed once from two plates of Bacillus cereus Selective Agar Base (BCSA) supplemented with Bacillus cereus selective supplement and egg yolk emulsion (Scharlau, Barcelona, Spain) after 24 hours of incubation at $30^{\circ} \mathrm{C}$.

\section{Exposures}

An overview of the experiments conducted is given in Table 1. In order to reduce non-exposure related variation, the control group and exposure groups were run simultaneously and all mice were handled by the same staff.

\section{Validation of inhaled dose and CFU recovery from BAL fluids (experiments 1 and 2)}

In order to validate the inhaled dose during the aerosol exposure, two groups of 5 mice each were exposed to two different concentrations of Vectobac ${ }^{\circledast}$ for one hour and the lungs were excised at the end of exposure. The theoretically inhaled dose per mouse was compared to the actual deposited dose. The theoretically inhaled dose was calculated as: aerosol concentration $\times$ the total volume of inhaled air per mouse during the $60 \mathrm{~min}$ exposure period. The aerosol concentration during the exposure was calculated from the CFU determined by Gesamtstaubprobenahme (GSP) filter sampler sampling throughout the exposure (BGI Inc., Waltham, MA, USA). The mean inhaled volume of air during one hour exposure per mouse calculated from the obtained respiration data (respiratory rate $\left(\mathrm{min}^{-1}\right) \times$ tidal volume $(\mathrm{mL}) \times 60 \mathrm{~min}$ ) and was determined to be $2.52 \mathrm{~L} /$ hour per mouse. The actual deposited dose was determined by CFU in the total lung homogenate (without a preceding BAL procedure). CFU determinations performed once on BCSA as described above.

In order to compare CFU recovery from total lung homogenate to the CFU recovery from extracted BAL fluid, 8 mice were exposed to Vectobac ${ }^{\oplus}$ via aerosol exposure for 1 hour. BAL was performed on 4 mice and the lungs were excised from all 8 mice and homogenised. BAL fluids, homogenate of lavaged and unlavaged lungs were all plated on BCSA plates for the determination of CFU as described and compared.

The aerosols were also monitored for particle size distribution during exposure by aerodynamic particle sizer (APS-3321, TSI inc., Shoreview, MN, USA), and for real-time particle counts by a Lighthouse 3016 particle counter (LHPC) (Lighthouse Worldwide Solutions, Fremont, CA, USA)

\section{Intratracheal instillations (experiments 3-5)}

The mice were anesthetized before instillation by intra peritoneal injection with Hypnorm ${ }^{\oplus}$ (Veta Pharma Ltd., Leeds, UK) and Dormicum ${ }^{\oplus}$ (Roche AG, Basel, Switzerland). The mice were exposed intra tracheal (i.t.) once with $50 \mu \mathrm{L}$ volume of inoculum using a flexible polyethylene tube attached to a syringe. The control animals were instilled with $50 \mu \mathrm{L}$ of sterile pyrogen-free water. Correct insertion of the tube into the trachea was assured by using a modified pneumotachometer 
Table 1 Experimental overview

\begin{tabular}{|c|c|c|c|c|c|c|c|}
\hline $\begin{array}{l}\text { Exp. } \\
\text { No. }\end{array}$ & Aim of experiment & $\begin{array}{l}\text { Number } \\
\text { of mice }\end{array}$ & $\begin{array}{l}\text { Exposure } \\
\text { method }\end{array}$ & Substance & $\begin{array}{l}\text { Time } \\
\text { Endpoint }\end{array}$ & Endpoint & $\begin{array}{l}\text { Corresponding } \\
\text { figure }\end{array}$ \\
\hline 1 & Validation of Inhalation dose & 10 & $\begin{array}{l}\text { Inhalation } \\
\text { (1 hour) }\end{array}$ & Vectobac $^{\oplus}$ & $1 \mathrm{~h}$ & $\begin{array}{l}\text { CFU from total lung } \\
\text { homogenate }\end{array}$ & Figure 1 \\
\hline 2 & Validation of CFU recovery from BALF & 8 & Inhalation & Vectobac $^{\circledast}$ & $1 \mathrm{~h}$ & $\begin{array}{l}\text { CFU from BALF and lavaged } \\
\text { lungtissue }\end{array}$ & None \\
\hline 3 & $\begin{array}{l}\text { Dose- response relationship B.t } \\
\text { israelensis }\end{array}$ & 25 & Instillation & Vectobac $^{\oplus}$ & $24 \mathrm{~h}$ & Inflammatory cells in BALF & Figure 2 \\
\hline 4 & $\begin{array}{l}\text { Time- response relationship B.t } \\
\text { israelensis or B.t kurstaki }\end{array}$ & 42 & Instillation & $\begin{array}{l}V_{\text {Vectobac }}^{\oplus} \text { or } \\
\text { Dipel }^{\oplus} \\
\text { (washed) }\end{array}$ & $\begin{array}{l}4 h, 24 h, \\
4 \text { days }\end{array}$ & $\begin{array}{l}\text { CFU and inflammatory cells in } \\
\text { BALF }\end{array}$ & Figure 3 \\
\hline 5 & $\begin{array}{l}\text { Sub-chronic effects of i.t instillations of } \\
\text { B.t israelensis or B.t kurstaki }\end{array}$ & 20 & Instillation & $\begin{array}{l}\text { Vectobac }{ }^{\circledast} \text { or } \\
\text { Dipel }^{\oplus}\end{array}$ & 70 days & $\begin{array}{l}\text { CFU, Inflammatory cells in } \\
\text { BALF, Histology }\end{array}$ & $\begin{array}{l}\text { Figure } 4 \\
\text { Figure } 5\end{array}$ \\
\hline 6 & $\begin{array}{l}\text { Sub-chronic effects of repeated } \\
\text { inhalations of B.t israelensis or B.t } \\
\text { kurstaki }\end{array}$ & 18 & $\begin{array}{l}\text { Inhalation } \\
\text { (Repeated) }\end{array}$ & $\begin{array}{l}\text { Vectobac }^{\oplus} \text { or } \\
\text { Dipel }^{\oplus}\end{array}$ & 70 days & $\begin{array}{l}\text { Airway irritation, CFU, } \\
\text { Inflammatory cells in BALF, } \\
\text { Histology }\end{array}$ & Figure 5 \\
\hline
\end{tabular}

Mice were exposed to Bt israelensis $\left(\right.$ Vectobac $\left.^{\circledast}\right)$ or Bt kurstaki $\left(\right.$ Dipel $\left.^{\circledast}\right)$ by either intratracheal instillation or inhalation of bacterial suspension. At 4 hours $(\mathrm{h}), 24 \mathrm{~h}$, 4 days or 70 days after exposure, lungs were lavaged and the bronchoalveolar lavage fluid (BALF) was analysed for content of colony forming units (CFU) and inflammatory cells. Furthermore, histological examination of the lung tissue was performed where specified.

(National Research Centre for the Working Environment, Copenhagen, Denmark) [12]. To establish a timeresponse relationship (experiment 4), 10 mice per dose were exposed by i.t instillations to either $3.4 \times 10^{6} \mathrm{CFU}$ Vectobac $^{\circledast}$ or $3.5 \times 10^{5} \mathrm{CFU} \mathrm{Dipel}^{\circledast}$. BAL fluids were collected 4 hours, 24 hours or 4 days post exposure and cells were counted and differentiated as described below.

Subsequently, in order to establish a dose-response relationship (experiment 3), 10 mice per dose was exposed by i.t instillations to a Vectobac $^{\oplus}$ dose of $1.25 \times$ $10^{4}, 2 \times 10^{5}, 4.2 \times 10^{5}$ or $1.2 \times 10^{6}$ CFU, respectively. BAL fluids were collected 24 hours post exposure and cells were counted and differentiated as described below.

For the sub-chronic study (experiment 5) the instilled doses were $3.4 \times 10^{6} \mathrm{CFU}$ for Vectobac ${ }^{\circledR}$ and $3.5 \times 10^{5}$ for Dipel $^{\circledR}$.

\section{Repeated aerosol inhalations (experiment 6)}

Mice ( $\mathrm{n}=9$ per group) were inserted into body plethysmographs that were connected to the exposure chamber. The respiratory parameters were obtained for each mouse from a Fleisch pneumotachograph connected to each plethysmograph that allows continuously monitoring of the parameters $[13,14]$. The exposures were preceded by a period that allowed the mice to adapt to the plethysmographs. Then, a 15 min. period was used to establish baseline (control) values of the respiratory parameters. This period was followed by a $60 \mathrm{~min}$. exposure period and a $15 \mathrm{~min}$ recovery period. Mice were exposed $60 \mathrm{~min} /$ day for 5 days per week for two weeks with a two-day break in-between. The dose of 5 $\times 10^{4} \mathrm{CFU}$ per mouse per exposure was chosen to mimic occupational exposure [15]. Suspensions of bacteria were delivered from a glass syringe, administered by an infusion pump (New England Medical Instruments Inc., Medway, MA, USA) and via a polyethylene tube connected to a Pitt. No. 1 aerosol generator [16]. The aerosol was mixed through a Vigreaux-column and led to a glass/stainless steel exposure chamber as described [17]. Total flow rate through the chamber was $20 \mathrm{~L} / \mathrm{min}$ and the air input through the aerosol generator was $14 \mathrm{~L} / \mathrm{min}$. The aerosol generator and all related equipments were thoroughly cleaned between exposure sessions. During the aerosol exposures, air samples were collected from the breathing zone of the mice for determination of particle size distribution, real-time particle counts and aerosol CFU concentration. This was done by APS at a flow of $5 \mathrm{~L} / \mathrm{min}, \mathrm{LHPC}$ at $2 \mathrm{~L} / \mathrm{min}$ and by a filter method GSP at $3.5 \mathrm{~L} / \mathrm{min}$. The APS monitored the size distribution of particles in the range from 0.542 to $19.81 \mu \mathrm{m}$ (aerodynamic diameter) in the exposure chamber. Real time particle counts in the exposure chamber was counted by LHPC in the ranges 0.7-2.0 $\mu \mathrm{m}$ and was used for a real time indicator of aerosol concentration. The GSP samplers were mounted with $0.8 \mu \mathrm{m}$ polycarbonate filters with airflow of $3.5 \mathrm{~L} / \mathrm{min}$. All filters were extracted in $5 \mathrm{~mL}$ sterile $0.05 \%$ Tween80 in $0.9 \% \mathrm{NaCl}$ solution by shaking for $15 \mathrm{~min}$ at room temperature $(500 \mathrm{rpm})$ in orbital shaking glass flasks and serial dilutions were made for determination of CFU (see above). Determination of respiratory parameters for assessment of irritation in upper respiratory tract, conducting airways and alveolar region, respectively was performed as thoroughly described [18]. Briefly, three types of effects from the respiratory system can be studied simultaneously:

a) Sensory irritation. In humans, chemicals stimulating the trigeminal nerve endings of the upper respiratory 
tract cause irritation that may increase to burning and painful sensations, termed 'sensory irritation'. Formaldehyde, ammonia and methacrolein are examples of compounds being sensory irritants [18-20]. Sensory irritants decrease the respiratory rate in mice due to a reflex causing a break at the end of the inspiratory phase [21].

b) Bronchial constriction. Airflow limitation due to bronchial constriction or inflammation of the conducting airways causes a lengthening of the duration of expiration and thus causes an associated decrease in respiratory rate. To quantify this effect, the airflow rate during expiration is measured.

c) Pulmonary irritation is caused by stimulation of vagal nerve endings at the alveolar level [22]. Stimulation of this reflex is characterized by a pause at the end of expiration, which is a specific marker of pulmonary irritation. Ozone is an example of a substance inducing pulmonary irritation [18].

The assessments and quantifications of the respiratory frequency, time of inspiration, time of expiration, time from end of inspiration until the beginning of expiration termed "time of brake", time from end of expiration until beginning of the next inspiration termed "time of pause", tidal volume and mid-expiratory flow rate were performed using the Notocord Hem software (Notocord Systems SA, Croissy-sur-seine, France) as described in details previously [23].

For the comparison of CFU recovered from total lung homogenate to that of CFU recovered from BAL fluid, a pilot inhalation experiment with 8 mice was performed.

\section{BAL procedure}

The BAL procedure was performed as previously described with minor modifications (Larsen et al., 2007). Briefly, the lungs were flushed four times with $0.8 \mathrm{~mL}$ saline $(0.9 \%)$ and the recovered fluids were pooled for each mouse. From the BAL fluid of mice that have received bacterial inocula, a $250 \mu \mathrm{L}$ of total fluid was removed before centrifugation for CFU determination. Cells were counted and differentiated by morphology into neutrophils, lymphocytes, macrophages, epithelial cells and eosinophils. For each sample, 200 cells were differentiated.

\section{Histopathology}

The chest of the mice was opened and a polyethylene tube introduced into the trachea. The polyethylene tube was connected to a syringe containing $4 \%$ buffered paraformaldehyde, and the lungs were inflated in situ with the fixative to normal size. After 5 minutes the lungs were removed in toto and further fixated for at least 24 hours. Tissues were embedded in paraffin in a standardized way (horizontal cut through the hilum regions) and subsequently $7 \mu \mathrm{m}$ thick slices were cut and stained with haematoxylin/periodic acid Schiff (PAS). The degree of inflammation and morphological changes in the lungs were evaluated blindly by microscopy by two experienced researchers and revaluated in case of discrepancy as described previously [24].

\section{Statistics}

The numbers of inflammatory cells in biopesticideexposed mice were compared to the control group by means of non-parametric analysis of variance (KruskallWallis). In case of significant difference in the KruskallWallis test, pair-wise comparisons between the water control group and the biopesticide-exposed animals were further analysed using the Mann-Whitney's U-test. Statistical significant difference was accepted at $\mathrm{p}<0.05$.

\section{Results}

Validation of actual deposited dose after inhalation

Comparing the theoretically inhaled dose of Vectobac ${ }^{\oplus}$ $\left(3.5 \times 10^{4} \mathrm{CFU}\right)$ and actual deposited dose $\left(2.9 \times 10^{4}\right.$ $\mathrm{CFU}$ ) revealed that $83 \%$ of the theoretically inhaled dose was deposited. For the $10 \times$ higher concentration, the mean theoretically inhaled dose was $5.6 \times 10^{5} \mathrm{CFU}$ and actual deposited dose was $5.1 \times 10^{5} \mathrm{CFU}$, i.e. $91 \%$ was deposited. The particle counts from APS and LHPC particle counters were stable throughout the exposure (Figure $1)$.

\section{CFU recovery from BAL fluid and from total lung homogenate}

Comparison of the CFU present in total lung homogenate to the CFU recovered from BAL fluid revealed that an average of $13 \%$ (range 10-20\%) of the total CFU was recovered by the BAL procedure. The remaining $80-90 \%$ of the CFUs were recovered from the lung homogenate of the flushed lungs.

\section{Acute inflammatory response to biopesticide instillation}

A clear dose-dependent increase in number of neutrophils was apparent 24 hours post i.t. instillation of the biopesticide Vectobac ${ }^{\oplus}$. Statistically significant increased numbers of neutrophils were seen after instillation of 2 $\times 10^{5} \mathrm{CFU}$ or more. Furthermore, at the $1.2 \times 10^{6} \mathrm{CFU}$ $V$ ectobac $^{\oplus}$ dose a significant increased number of lymphocytes and eosinophils were seen (Figure 2).

The inflammatory responses seen as neutrophils in BALF due to Vectobac ${ }^{\oplus}$ and Dipel $^{\oplus}$ exposures were similar over time as apparent from (Figure 3). No change in cell count or distribution was observed 4 hours after instillation compared to that of the vehicle (sterile water) control groups, but 24 hours post exposure, a significantly increased number of neutrophils were observed for $\operatorname{Dipel}^{\circledast}(p=0.03)$ as well as Vectobac ${ }^{\circledast}(p=0.0001)$. Four days after exposure, elevated numbers of 


\section{Aerosol characteristics and TID vs ADD}

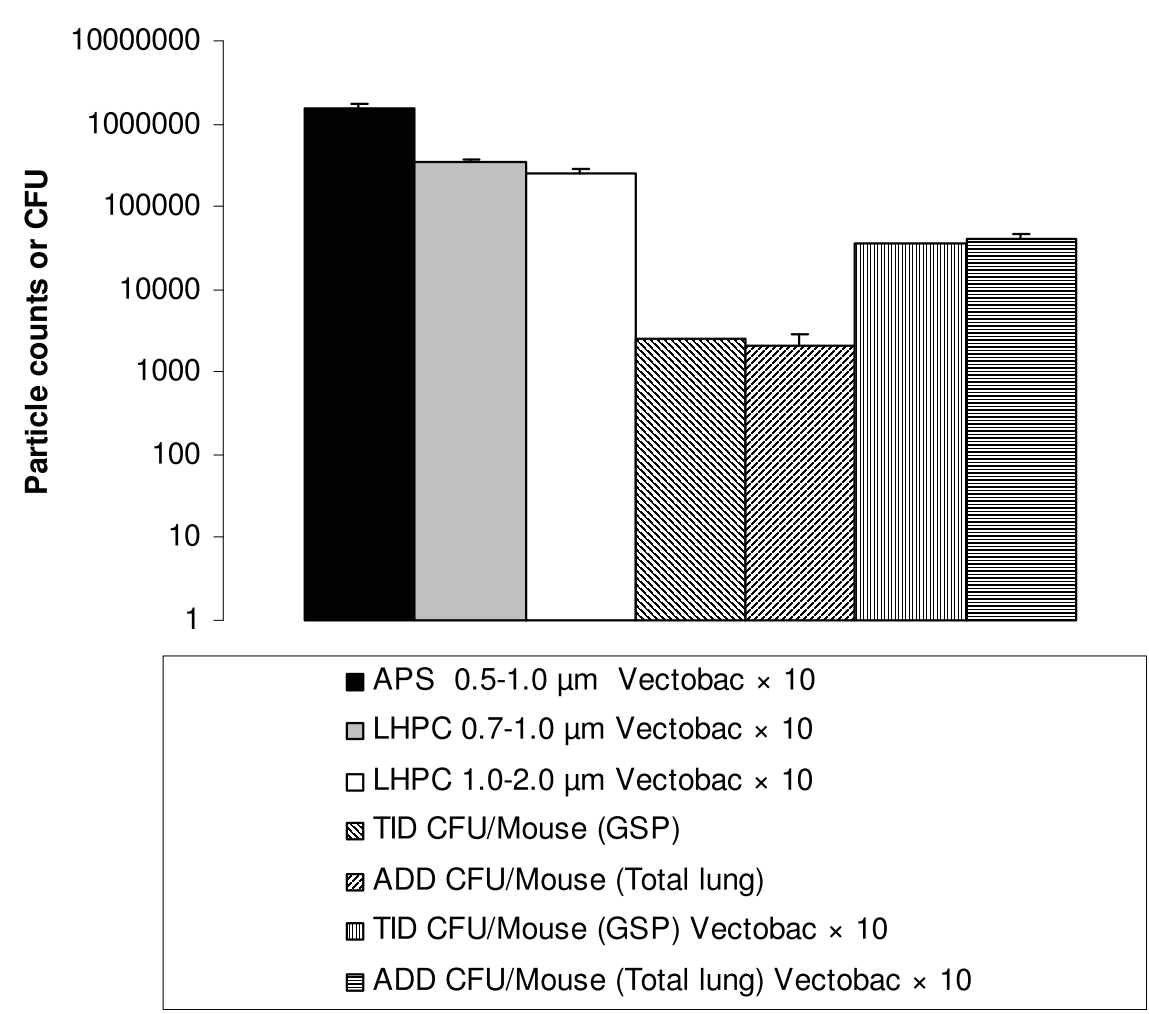

Figure 1 Aerosol characteristics and validation of actual deposited dose (ADD) per mouse. Particles (counts $\min ^{-1}$ ) of the Vectobac $\times 10$ exposure aerosol were measured by APS $(n=21)$ and LHPC $(n=24)$ for different particle sizes. The theoretically inhaled dose (TID) per mouse based on CFU measurements from a GSP filter sampler were compared to the ADD per mouse ( $n=5$ per group) for the two different exposure concentrations. Values are means with SEM.

macrophages and neutrophils were seen for both $\mathrm{Dipel}^{\circledR}$ and Vectobac ${ }^{\oplus}$. Furthermore, exposure to Vectobac ${ }^{\oplus}$ gave rise to an increased number of eosinophils (Figure 3).

\section{Assessment of acute airway irritation after exposure to biopesticide aerosols}

For both Vectobac ${ }^{\circledR}$ and Dipel ${ }^{\oplus}$, nine mice were exposed to aerosolised product in the head-only exposure chamber. The aerosols were monitored for both particle counts by LHPC and for size-distribution by APS. The majority of the particles in the generated aerosol were between 0.8 and $2.0 \mu \mathrm{m}$ with a peak count at $1 \mu \mathrm{m}$, which is equal to the size of Bt spores [25]. Each mouse received a theoretically inhaled dose of $1.9 \times 10^{4} \mathrm{CFU}$ Bt israelensis or $2.3 \times 10^{3} \mathrm{CFU}$ Bt kurstaki per exposure. Respiratory parameters were collected during the first 60 min of exposure to assess airway irritation. The results showed no alterations in respiratory rate, time of brake or time of pause when compared to baseline levels, i.e. airway irritation was apparent neither from the nose nor from the lungs (data not shown).
Recovery of CFU from the sub-chronic (70 days) inhalation and aerosol studies

All BAL fluids from the sub-chronic studies were also subjected to a CFU count (Figure 4). In the mice instilled with $3.4 \times 10^{6}$ CFU Vectobac ${ }^{\otimes}$ (8 of 10 mice) bacteria were still present in the BALF with an average of $150 \mathrm{CFU} / \mathrm{BALF}$. Only one mouse out of 9 instilled with $3.5 \times 10^{5}$ CFU Dipel ${ }^{\oplus}$ had CFU recovered after 70 days (2850 CFU/BALF). In the mice exposed by inhalation to Dipel $^{\circledast}$ aerosols, one mouse out of 10 had CFU recovered (630 CFU/BALF). No CFU was recovered from mice exposed to Vectobac $^{\oplus}$ aerosol.

\section{Histopathology from the sub-chronic (70 days) studies} (experiments 5 and 6)

\section{Effects of i.t. instillation}

All 20 mice that received high doses of biopesticide by i.t. instillation showed tissue changes for both commercial products 70 days after exposure. The most pronounced changes were observed in the group given Vectobac $^{\circledast}$. The changes were localized in focal areas 

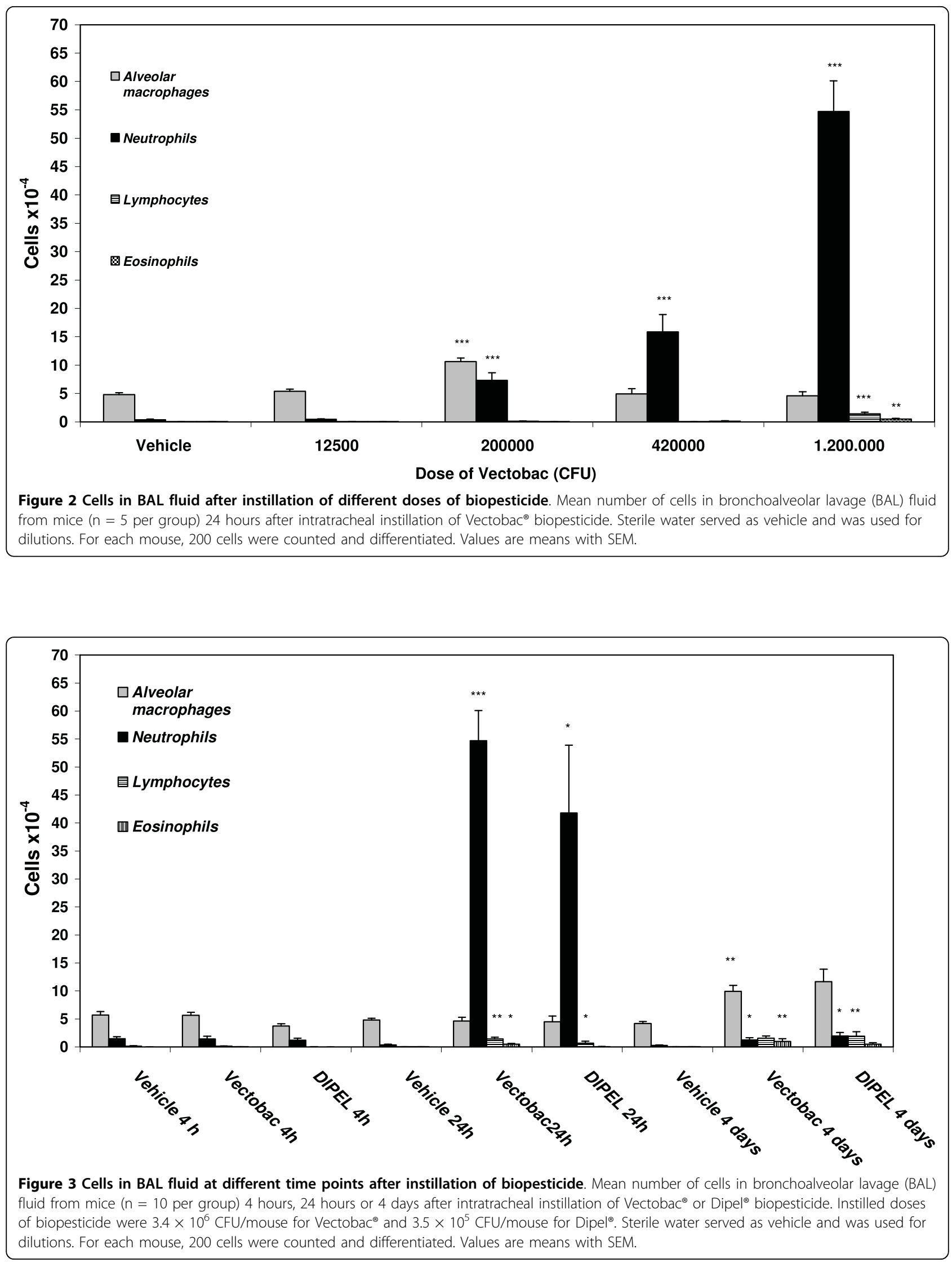


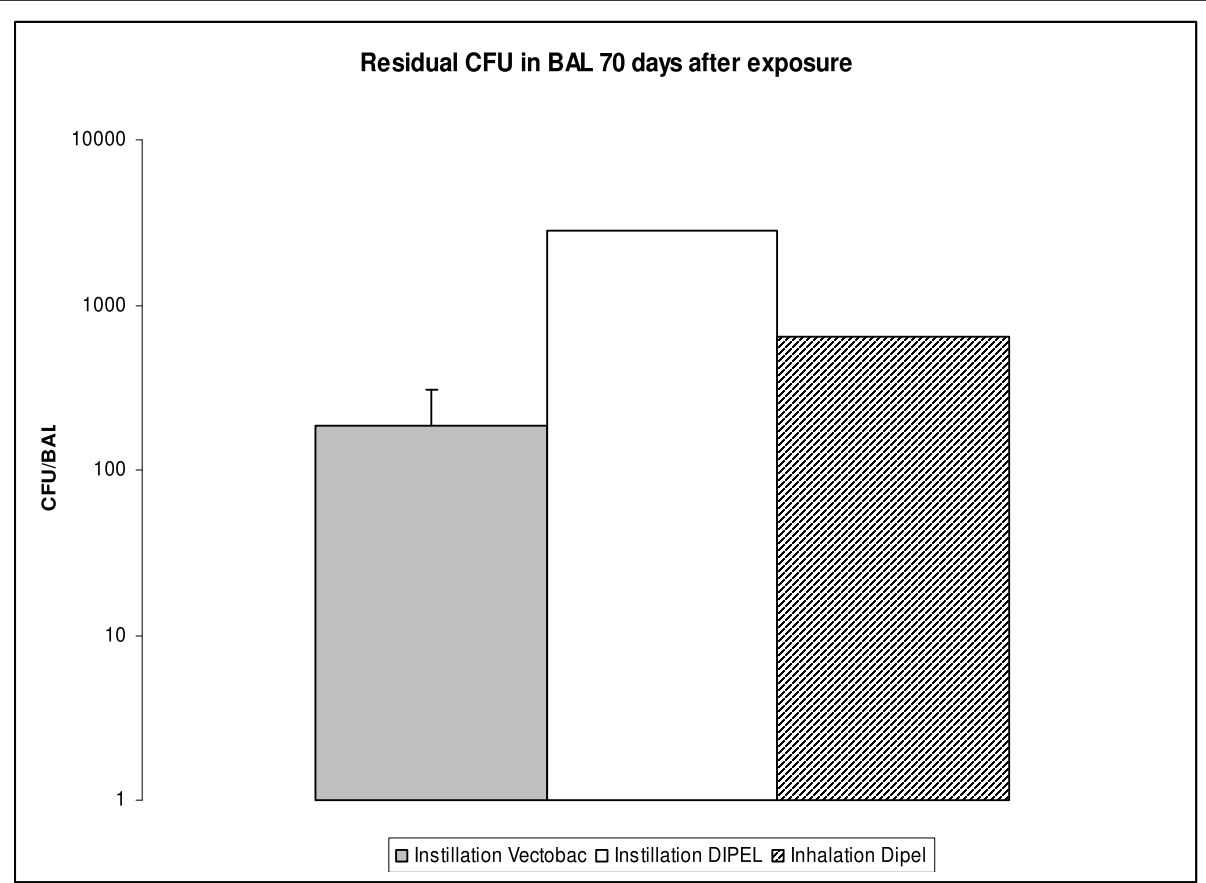

Figure 4 Number of residual CFU recovered from BAL fluid 70 days after instillation. For Vectobac ${ }^{\circledast}$ the value is mean with SEM for the responding mice (8 out of 10). For Dipel ${ }^{\oplus}$ instillation or Dipel ${ }^{\oplus}$ inhalation, data represent residual CFU from 1 out of 9 and 1 out of 10 mice, respectively.

adjacent to the larger blood vessels. The dominating cell type was lymphocytes but also plenty of neutrophils and macrophages containing particles were present. The PAS positive material is unidentified material from the biopesticide remaining in the lungs. The sub-chronic inflammation was apparent as small patches of interstitial inflammation, affecting approximately $5 \%$ of the lung surface. The degree of inflammation varied considerably within the lung with the most pronounced changes being localized to the lower, posterior part of the lung and only minor changes were observed in the peripheral parts of the lung tissue. Slight interstitial inflammation was observed after Vectobac ${ }^{\oplus}$ instillation (Figures 5C-E). In the larger bronchi, goblet cell formations comparable to experimental bronchitis was observed.

Instillation of Dipel ${ }^{\oplus}$ resulted in fewer and less intense changes. The typical changes were small focal areas with accumulation of inflammatory cells interstitially and inflammation was observed also peripherally even to the level of the pleura (Figure 5F).

\section{Effects of aerosol exposure}

Histology suggested that one mouse had developed leukaemia. In consequence, data from this mouse was excluded from further analyses. In 3 of the remaining 17 mice, some patches of interstitial inflammation were observed 70 days after end of the repeated exposures to
Vectobac $^{\oplus}$ (Figure 5G and 5H), whereas exposure to Dipel $^{\oplus}$ gave rise to less significant effects (not shown).

\section{Discussion}

The Bt based biopesticides are generally considered a safe and greener alternative to chemical pesticides. The commercial Bt species are believed to be non-infectious and have only on rare occasions been associated with opportunistic infections in humans. Nevertheless, the close relationship between Bt and the human pathogen Bacillus cereus continues to be substantiated and gives rise to new questions [26-29].

The present study showed that instilled or even inhaled Bt spores may be present in the lung and extracted by BAL 70 days after administration. Our data are in line with other clearance studies, demonstrating CFU of Bt kurstaki in the liver, spleen and lungs 21 days after intratracheal (i.t.) instillation and similar patterns were seen with Bt aizawai and B. subtilis. Clearance patterns after i.v. injection with $10^{7} \mathrm{CFU}$ per animal is also reported for Bt kurstaki, Bt israelensis, $B$. subtilis and B. sphaericus. All strains were still recovered from inner organs at the termination of the study (day 57 for Bt israelensis and 128 for Bt kurstaki) [30,31].

As Bt formulations are used for spray application, hazard identification and risk assessment should be based on airway effects. To our knowledge, the present study is the first to investigate airway irritation and 

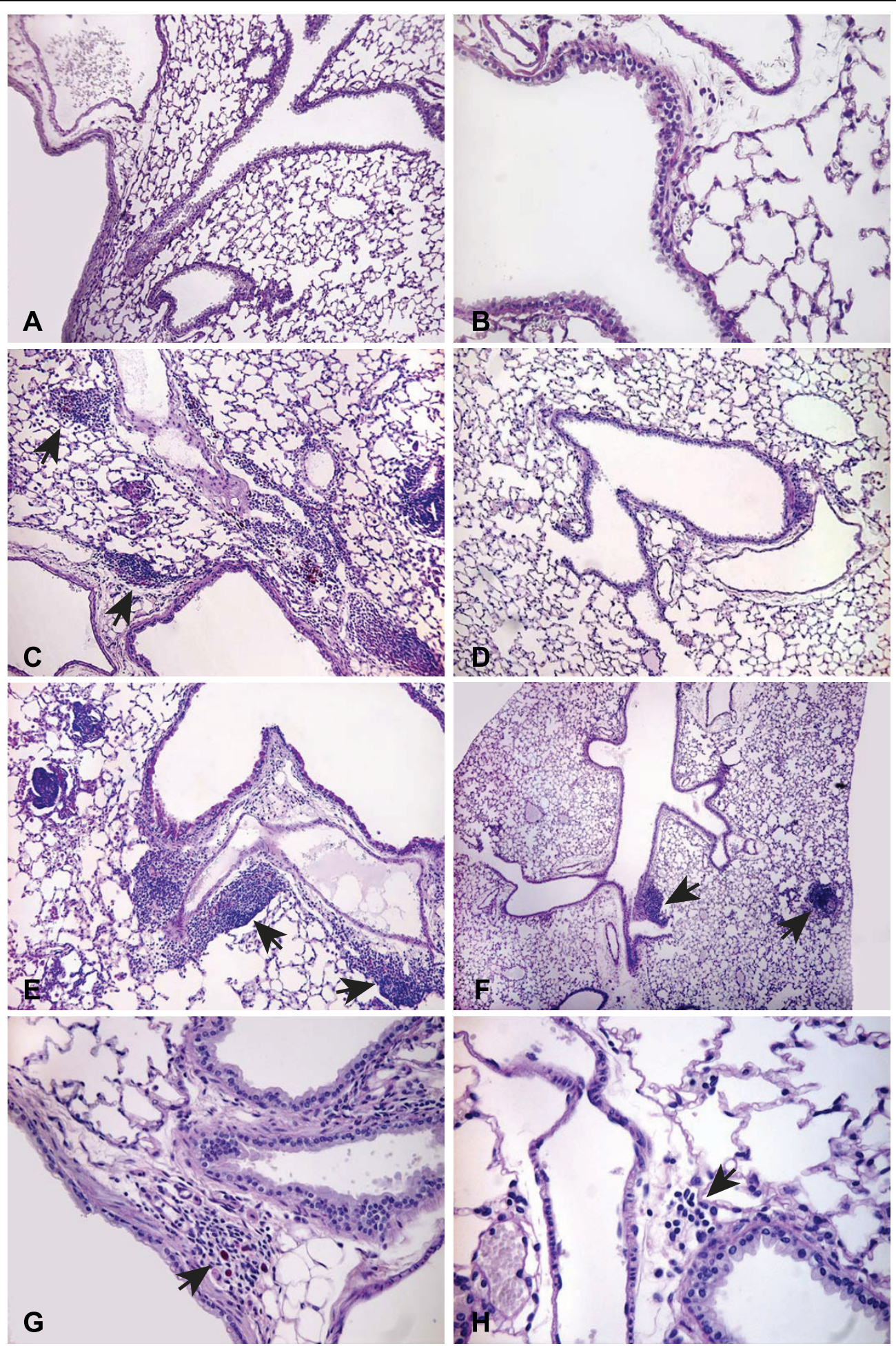

Figure 5 Lung histology sections from mice $\mathbf{7 0}$ days after exposure to biopesticide. Arrows indicate interstitial inflammation with PAS positive foreign materials. Exposures were $50 \mu \mathrm{L}$ of sterile pyrogen-free water (Controls), Vectobac ${ }^{\oplus}$ or Dipel ${ }^{\oplus}$ through a single intratracheal instillation (A-F) or repeated $(2 \times 5 \times 1 \mathrm{~h})$ aerosol exposures $(\mathrm{G}-\mathrm{H})$. Control slides (A-B) show the pulmonalis and bronchiole wall and with no inflammatory changes. Interstitial inflammation is apparent after Vectobac ${ }^{\circledast}$ instillation (C-E) as indicated by arrows. Instillation of Dipel ${ }^{\circledR}$ resulted in small focal areas with accumulation of inflammatory cells interstitially and inflammation was observed also peripherally even to the level of the pleura (F). Patches of interstitial inflammation were also observed in 3 out of 17 mice after repeated aerosol exposures to Vectobac ${ }^{\circledR}(\mathrm{G}-\mathrm{H})$. Sections are stained with periodic acid-Schiff (PAS). Magnifications were $\times 32(F), \times 80(A, C, D, E), \times 200(B, G)$ or $\times 320(H)$. 
airway inflammation induced by inhalation of commercial Bt biopesticides. The i.t. instillation of biopesticide, showed that a single exposure gave rise to focal areas of lung tissue inflammation still detectable 70 days after exposure. A clear dose-response relationship was seen. Inflammation was also seen 70 days after repeated inhalation of Bt biopesticide, although the effects after inhalation were less vigorous than after instillation. The sub-chronic inflammation was apparent as small patches of interstitial inflammation, a response that was not detectable in the corresponding BAL fluid. The subchronic inflammation observed in the present study, was most likely due to the prolonged presence of Bt spores or other product residues in the lungs, triggering and maintaining the inflammatory response. This should be seen in the light that the formulated biopesticides contains only about $2 \%$ spores and $98 \%$ other ingredients according to manufacturer which makes long term inhalation studies using the final formulated biopesticide important. The list of other ingredients besides water is known to authorities (e.g. the EPA) and approved for other purposes e.g. a "food- carbohydrate" and preservatives [32]. Most of these other ingredients have probably not been subjected to long term inhalation studies in animals as this was not their intended use. Therefore alternative inoculums or controls, including spore free or heat-inactivated biopesticide or specific excipients/ additives should also be studied for biological effect. In the case of low clearance rates, as demonstrated in this study, the inflammation could be prolonged or even become chronic which may potentially initiate the development of severe health effects such as chronic obstructive pulmonary disease [33] or formation of fibrotic lung tissue [34].

In experiments 3, 5 and 6 the exposure concentrations of Dipel ${ }^{\oplus}$ were almost a 10 -fold lower than Vectobac ${ }^{\oplus}$ and the lower effects and tissue changes of the exposures with Dipel ${ }^{\otimes}$ should be seen in this light. This difference is also shown as the recovery of CFU still present in the BAL fluids 70 days after instillation with different inoculums of two biopesticides. The lower concentrations were chosen on the basis of experiment 4, where a washing procedure of the $\mathrm{Dipel}^{\circledR}$ product was necessary due to viscosity. A pilot experiment revealed that the washing procedure did not change the inflammatory properties of the product. Upon dilution of the $\mathrm{Dipel}^{\ominus}$, the viscosity was acceptable for instillation, wherefore suspensions of the unaltered commercial Dipel $^{\oplus}$ product were used.

Our study has also demonstrated that exposure to aerosolized Vectobac ${ }^{\oplus}$ did not induce airway irritation upon inhalation. This is important in regards to occupational hazard as the absence of discomfort by exposure would make workers less inclined to wear the recommended protective filter facemask while working with the biopesticide.

\section{Conclusions}

Repeated exposure to biopesticide aerosols may lead to sub-chronic lung inflammation which may contribute to the development of severe lung diseases. No airway irritation was observed upon inhalation of Bt aerosols, suggesting that exposure will not evoke a warning signal, making the exposure insidious.

The present study emphasises the need for additional studies assessing lung effects after long-term, repeated exposures to low and occupationally relevant concentrations of Bt biopesticide aerosols.

\section{List of abbreviations used}

APS: Aerodynamic particle sizer; ADD: Actual deposited dose; BAL(F): Bronchoalveolar lavage (fluids); BCSA: Bacillus cereus selective agar; Bt: Bacillus thuringiensis; CFU: Colony forming units; COPD: Chronic obstructive pulmonary disease; GSP: Gesamtstaubprobenahme sampler; I.t.: Intra tracheal; LHPC: Lighthouse handheld particle counter; NOEL: No-observed effect level; PAS: Periodic acid Schiff; TID: Theoretically inhaled dose

\section{Acknowledgements}

This work was in part supported by ilochip A/S, Denmark. We thank Gitte B. Kristensen, Michael Guldbrandsen and Heidi Paulsen for excellent technical support.

\section{Author details}

${ }^{1}$ National Research Centre for the Working Environment, Copenhagen, Denmark. ${ }^{2}$ Statens Serum Institut, Copenhagen Denmark. ${ }^{3}$ Department of Biomedical Research, The Panum Institute, University of Copenhagen, Copenhagen, Denmark.

\section{Authors' contributions}

KKB, MHA and STL designed the studies and planned the experiments. KKB MHA and SSP conducted the laboratory work. KKB, SSP and STL interpreted the data. KKB drafted the first version of the manuscript. All authors contributed to and approved the final manuscript.

Received: 25 May 2010 Accepted: 3 September 2010

Published: 3 September 2010

\section{References}

1. Glare RTravis, O'Callaghan Maureen: Bacillus thuringiensis: Biology, Ecology and Safety John Wiley and Sons, LTD 2000.

2. Schnepf E: Bacillus thuringiensis and its pesticidal crystal proteins. Microbiol Mol Biol Rev 1998, 62:775-806.

3. Drobniewski FA: Bacillus cereus and related species. Clin Microbiol Rev 1993, 6:324-338.

4. Doekes $G$, Larsen P, Sigsgaard T, Baelum J: IgE sensitization to bacterial and fungal biopesticides in a cohort of Danish greenhouse workers: the BIOGART study. Am J Ind Med 2004, 46:404-407.

5. Elliott $J$, Sokolow $R$, Heumann M, Elefant SL: An exposure characterization of a large scale application of a biological insecticide, Bacillus thuringiensis. Applied Industriel Hygiene 1988, 3:119-122.

6. Jensen $G B$, Larsen $P$, Jacobsen BL, Madsen B, Wilcks A, Smidt L, et al: Isolation and characterization of Bacillus cereus-like bacteria from faecal samples from greenhouse workers who are using Bacillus thuringiensisbased insecticides. Int Arch Occup Environ Health 2002, 75:191-196. 
7. Bernstein IL, Bernstein JA, Miller M, Tierzieva S, Bernstein DI, Lummus Z, et al: Immune responses in farm workers after exposure to Bacillus thuringiensis pesticides. Environ Health Perspect 1999, 107:575-582.

8. Illing HP: Is working in greenhouses healthy? Evidence concerning the toxic risks that might affect greenhouse workers. Occup Med (Lond) 1997, 47:281-293.

9. Noble MA, Riben PD, Cook GJ: Microbial and Epidemiological Surveillance Programme to Monitor the Health Effects of Foray 48B BTK Spray. Report to the Ministry of Forests, Province of British Columbia, Vancouver, Canada 1992, Ref Type: Report.

10. Carrera M, Zandomeni RO, Fitzgibbon J, Sagripanti JL: Difference between the spore sizes of Bacillus anthracis and other Bacillus species. J Appl Microbiol 2007, 102:303-312.

11. Menache MG, Miller FJ, Raabe OG: Particle inhalability curves for humans and small laboratory animals. Ann Occup Hyg 1995, 39:317-328.

12. Jacobsen NR, Moller P, Jensen KA, Vogel U, Ladefoged O, Loft S, et al: Lung inflammation and genotoxicity following pulmonary exposure to nanoparticles in ApoE-/- mice. Part Fibre Toxicol 2009, 6:2.

13. Vijayaraghavan R, Schaper M, Thompson R, Stock MF, Boylstein LA, Luo JE, et al: Computer assisted recognition and quantitation of the effects of airborne chemicals acting at different areas of the respiratory tract in mice. Arch Toxicol 1994, 68:490-499.

14. Boylstein LA, Luo J, Stock MF, Alarie Y: An attempt to define a just detectable effect for airborne chemicals on the respiratory tract in mice. Arch Toxicol 1996, 70:567-578.

15. Jensen GB, Larsen P, Jacobsen BL, Madsen B, Smidt L, Andrup L: Bacillus thuringiensis in fecal samples from greenhouse workers after exposure to B. thuringiensis-based pesticides. Appl Environ Microbiol 2002 68:4900-4905.

16. Wong KL, Alarie $\mathrm{Y}$ : A method for repeated evaluation of pulmonary performance in unanesthetized, unrestrained guinea pigs and its application to detect effects of sulfuric acid mist inhalation. Toxicol Appl Pharmacol 1982, 63:72-90.

17. Clausen SK, Bergqvist M, Poulsen LK, Poulsen OM, Nielsen GD: Development of sensitisation or tolerance following repeated OVA inhalation in BALB/cJ mice. Dose-dependency and modulation by the $\mathrm{Al}$ (OH)(3) adjuvant. Toxicology 2003, 184:51-68.

18. Nielsen GD, Hougaard KS, Larsen ST, Hammer M, Wolkoff P, Clausen PA, et al: Acute airway effects of formaldehyde and ozone in BALB/c mice. Hum Exp Toxicol 1999, 18:400-409.

19. Nielsen GD, Wolkoff $P$, Alarie Y: Sensory irritation: Risk assessment approaches. Regul Toxicol Pharmacol 2007, 48:6-18.

20. Larsen ST, Nielsen GD: Effects of methacrolein on the respiratory tract in mice. Toxicol Lett 2000, 114:197-202.

21. Alarie Y: Computer-based bioassay for evaluation of sensory irritation of airborne chemicals and its limit of detection. Arch Toxicol 1998, 72:277-282.

22. Vijayaraghavan $R$, Schaper M, Thompson R, Stock MF, Alarie Y: Characteristic modifications of the breathing pattern of mice to evaluate the effects of airborne chemicals on the respiratory tract. Arch Toxicol 1993, 67:478-490.

23. Larsen ST, Hansen JS, Hammer M, Alarie Y, Nielsen GD: Effects of mono-2ethylhexyl phthalate on the respiratory tract in BALB/c mice. Hum Exp Toxicol 2004, 23:537-545.

24. Roursgaard M, Poulsen SS, Kepley CL, Hammer M, Nielsen GD, Larsen ST: Polyhydroxylated C60 fullerene (fullerenol) attenuates neutrophilic lung inflammation in mice. Basic Clin Pharmacol Toxicol 2008, 103:386-388.

25. Carrera M, Zandomeni RO, Fitzgibbon J, Sagripanti JL: Difference between the spore sizes of Bacillus anthracis and other Bacillus species. J Appl Microbiol 2007, 102:303-312.

26. Carlson $C R$, Kolsto $A B$ : A complete physical map of a Bacillus thuringiensis chromosome. J Bacteriol 1993, 175:1053-1060.

27. Helgason E: Bacillus anthracis, Bacillus cereus, and Bacillus thuringiensis one species on the basis of genetic evidence. Appl Environ Microbiol 2000, 66:2627-2630

28. Salamitou S: The plcR regulon is involved in the opportunistic properties of Bacillus thuringiensis and Bacillus cereus in mice and insects. Microbiology 2000, 146:2825-2832.

29. Wilcks A, Smidt L, Bahl MI, Hansen BM, Andrup L, Hendriksen NB, et al: Germination and conjugation of Bacillus thuringiensis subsp. israelensis in the intestine of gnotobiotic rats. J Appl Microbiol 2008, 104:1252-1259.
30. McClintock JT, Sjoblad RD: A comparative review of the mammalian toxicity of bacillus thuringiensisbased pesticides. Pesticide Science 1995, 45:95-105.

31. Siegel JP, Shadduck JA: Clearance of Bacillus sphaericus and Bacillus thuringiensis ssp. israelensis from mammals. J Econ Entomol 1990, 83:347-355.

32. Valent Biosciences: Dipel ${ }^{\circledR}$ Foray ${ }^{\circledR}$. Forest Technical Manual 2001, 28-29.

33. Barnes PJ: Immunology of asthma and chronic obstructive pulmonary disease. Nat Rev Immunol 2008, 183-192.

34. Pardo A, Barrios R, Gaxiola M, Segura-Valdez L, Carrillo G, Estrada A, et al: Increase of lung neutrophils in hypersensitivity pneumonitis is associated with lung fibrosis. Am J Respir Crit Care Med 2000, 161:1698-1704.

doi:10.1186/1471-2180-10-233

Cite this article as: Barfod et al: Sub-chronic lung inflammation after airway exposures to Bacillus thuringiensis biopesticides in mice. BMC Microbiology 2010 10:233.

\section{Submit your next manuscript to BioMed Central and take full advantage of:}

- Convenient online submission

- Thorough peer review

- No space constraints or color figure charges

- Immediate publication on acceptance

- Inclusion in PubMed, CAS, Scopus and Google Scholar

- Research which is freely available for redistribution 